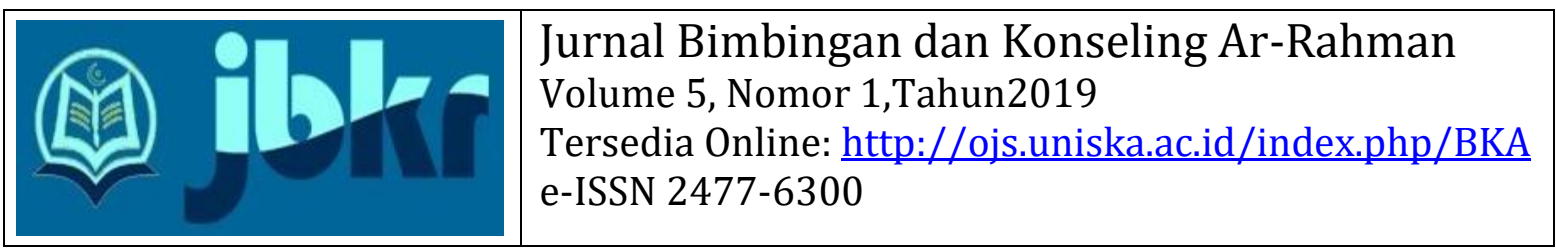

\title{
KEPRIBADIAN PROFESI KONSELOR ISLAMI DI ERA INDUSTRI 4.0
}

\author{
Ahmad Hartono \\ SMP Negeri 1 Jombang \\ ahmad.hart45@gmail.com
}

Revolusi industri 4.0 yang ditandai kemajuan teknologi digital; kecerdasan buatan, komputer kuantum, internet of things, kendaraan tanpa awak menimbulkan perubahan besar-besaran di berbagai bidang kehidupan, perubahan apapun dalam hidup ini akan mengakibatkan ketidak pastian, yang membutuhkan kemampuan untuk melakukan penyesuaian diri, kecemasan, ketakutan dan rasa putus asa tetapi pada waktu yang sama juga menumbuhkan harapan, semangat baru untuk melakukan pengembangan diri. Dinamika pasang-surut dalam hidup ini merupakan peran profesi konselor yang memiliki obyek praktik spesifik melakukan pengembangan individu dan mengentaskan masalah yang dapat mengganggu kehidupan efektif sehari-hari, dengan demikian maka profesi konselor adalah profesi kehidupan yang akan tetap eksis bersama kehidupan. Berdasarkan latar belakang tersebut artikel ini bertujuan merumuskan konsep kepribadian konselor islami sebagai aspek penting yang menentukan keberhasilan layanan konseling di era industri 4.0. Metode yang dipergunakan dalam pembahasan ini adalah deskriptif kualitatif melalui kajian kepustakaan yang bersumber dari al Qur'an, Hadits, sumber lain yang relevan sehingga nilai-nilai ajaran islam menjadi dasar pembentukan karakteristik kepribadian konselor islami yang diharapkan dapat menjadi solusi tuntutan perubahan dengan segala permasalahannya dan menjawab kebutuhan pengembangan diri dalam usaha mewujudkan layanan konseling yang memandirikan dan membahagiakan.

Kata kunci: Revolusi industri 4.0; profesi konselor; kepribadian konselor islami

\begin{abstract}
Revolution of industry 4.0 is marked by a digital technology development; artificial intelligence, quantum computer, internet of things, unmanned vehicle that cause big changer at any kinds of life sectors, any kinds of changes in this life affect uncertainty that need ability to adapt, worries, fear and hopeless, but at the same time, these cases also grow hopes, nuw spirit to do self development. Up and down dynamics in this life is a part of counselor profesion role whos has specific practice abyect do individual development and solve the problems that can broter daily afective lives. Thus counselor profession is life profession that will still exist together with lives. Based on the background above, the purpose of this article is to formulate concept of Islamic counselor profession as the important aspect to determine the success of counseling services of the era of industry 4.0. Method used in this discussion is qualitative descriptive through library study sourced from al Qur'an, hadits and other relevant sources so the values of islamic teachings as the base of forming characteristics of islamic counselor personality that is hope to be the solution of any change demends of problems and to respond the needs of self development as a way actualize own and exciting counseling service.
\end{abstract}

Keywords:Revolution of industry 4.0; counselor profesiion; personality of islamic counselor

Dipublikasikan Oleh :

UPT Publikasi dan Pengelolaan Jurnal

Universitas Islam Kalimantan Muhammad Arsyad Al-Banjari Banjarmasin 


\section{PENDAHULUAN}

Kemajuan ilmu pengetahuan dan teknologi melalui pengembangan riset dan penelitian menjadi pintu lahirnya revolusi industri, dimulai dari era revolusi industri pertama yang ditandai penemuan mesin uap pada tahun 1850 terjadi peralihan penggunaan tenaga kerja dari manusia dan hewan digantikan mesin berbasis manufaktur. Selanjutnya di akhir abad 18 memasuki revolusi industri kedua yang ditandai dengan penemuan mesin pembakaran dalam, pembangkit tenaga listrik yang menjadi dasar pembuatan pesawat telepon, pesawat udara, dll dan kemudian muncul penggunaan teknologi digital dan internet menandai memasuki revolusi industri 3.0 setiap pergantian era revolusi industri tersebut menimbulkan perubahan besar di bidang sosial, ekonomi, politik dan budaya.

Era industri 4.0 istilah yang berasal dari sebuah proyek dalam strategi teknologi canggih pemerintah Jerman yang dikenalkan di Honover Fair tahun 2011 yang ditandai penggunaan era digital dalam bidang kecerdasan buatan, robot, teknologi nano, komputer kuantum, bioteknologi, internet of things, percetakan 3 dimensi dan kendaraan tanpa awak dengan cara memadukan kemampuan mesin, digital dan manusia untuk berhubungan dan berkomunikasi antara satu dengan lainnya melalui Internet Untuk Segala (IoT), melalui IoT inilah dilakukan otomatisasi proses secara besar-besaran yang mengambil alih pekerjaan manusia. (Yahya M, 2018: 3)

Menurut Organisasi Buruh Internasional (ILO) sebagaimana disebut pada Pusat Studi Ekonomi dan Kebijakan Publik (PSEKP) Universitas Gajah Mada, diproyeksikan Indonesia akan memindahkan $56 \%$ pekerjaan ke otomatisasi pada beberapa dasawarsa ke depan. (https://psekp.ugm.ac.id) karena itu akan terjadi ribuan pekerjaan akan hilang, pengangguran meningkat dan profesi-profesi lama, seperti: penterjemah, tukang pos, kasir, pustakawan memudar meskipun tidak hilang sama sekali tetapi pada waktu yang sama muncul profesi-profesi baru yang tidak pernah kita kenal sebelumnya.

Revolusi industri 4.0 menyebabkan terjadinya perubahan besar secara cepat dan radikal mengubah kehidupan manusia. Perubahan yang menimbulkan ketidak pastian, kecemasan, terancam, putus asa tetapi sebaliknya perubahan bisa menumbuhkan harapan, rasa senang, peluang dan tantangan berinovasi. Dalam mengahadapi perubahan di era revolusi industri 4.0 tersebut bagaimana eksistensi profesi konselor?

Profesi konselor merupakan keahlian pelayanan pengembangan pribadi dan pemecahan masalah yang mementingkan pemenuhuan kebutuhan dan kebahagiaan pengguna sesuai dengan martabat, nilai, potensi dan keunikan individu berdasarkan kajian dan penerapan ilmu dan teknologi dengan acuan dasar ilmu pendidikan dan psikologi yang dikemas dalam kajian terapan konseling yang diwarnai oleh budaya pihak-pihak terkait. Untuk menghindari tumpah tindih dengan profesi lain Prayitno (2015: 31) menyebut sebagai obyek praktik spesifik profesi konselor, yaitu: Mengembangkan kondisi positif pribadi dan penanganan kondisi negatif yang dapat mengganggu kehidupan efektif sehari-hari.

Dalam kehidupan pribadi dan kehidupan sosial akan selalu dihadapkan pada perbedaan setiap pribadi dan perubahan kondisi yang menimbulkan munculnya masalah yang harus dientaskan dan keinginan untuk merubah diri terus berkembang menjadi lebih baik. Pasang-surut antara masalah dan penyelesaiannya, tantangan dan hambatan, menang dan kalah, sedih dan bahagia merupakan dinamika hidup bahkan hidup itu sendiri yang menunjukkan kebutuhan adanya profesi konselor sebagai profesi pelayanan bantuan terhadap sesama, karena itu profesi konselor merupakan profesi kehidupan, profesi yang akan dituntut terus berubah menyesuaikan kebutuhan pribadi dan masyarakat juga berbagai perubahan akibat revolusi industri 4.0

Keefektifan profesi konselor dalam melakukan layanan konseling ditentukan keutuhan pribadi konselor, meliputi: stabilitas, harmoni, kesetiaan dan tujuan yang penting bahkan menentukan perubahan pada diri klien dibandingkan pendidikan formal, ilmu pengetahuan, keahlian dan teknik layanan konseling (Glanding, 2015: 40)

Penelitian sebelumnya tentang karakteristik kepribadian konselor ideal pernah dilakukan oleh: Dody Riswanto, Andi Mappiare AT, M. Irtadji, (2016) Pascasarjana Universitas Malang, yang membahas tentang Kepribadian ideal konselor yang diserap dari nilai-nilai Peraturan Menteri Pendidikan no. 27/2008. Penelitian sebelumnya juga pernah dilakukan oleh: Samsul Arifin, Akhmad Zaini, (2014), Bimbingan Konseling Islam Fakultas Dakwah IAI Ibrahimy Situbondo, yang merumuskan kualitas kepribadian konselor dalam layanan konseling At Tawazun yang digali dari nilai-nilai pesantren.

Tulisan artikel dalam jurnal ini, membahas kepribadian konselor islami profesi konselor yang berbeda dari pembahasan dalam tulisan artikel-artikel sebelumnya. Kepribadian islami, merupakan ciri khas seorang individu dalam berfikir, merasa, bersikap dan berperilaku yang dibangun atas dasar nilai-nilai ajaran agama islam.

Hal ini dilakukan, karena: Islam agama yang sempurna dan agama yang diridhoi Allah, yang ditegaskan Allah dalam al Qur'an sebagai berikut: 


\section{Ahmad Hartono \\ Jurnal Bimbingan dan Konseling Ar-Rahman \\ Volume 5, Nomor 1, Tahun 2019 \\ e-ISSN 2477-6300}

"Pada hari ini telah Ku-sempurnakan untuk kamu agamamu dan telah Ku-cukupkan kepadamu nikmat$\mathrm{Ku}$ dan telah $\mathrm{Ku}$-ridhai Islam itu sebagai agama bagimu" (al Maidah: 3)

Kepribadian yang dibangun berdasarkan agama islam yang sempurna dan telah diridhai Allah akan menjadi kepribadian yang terbaik dan sempurna pula, sebagaimana difirmankan Allah berikut: "Kamu adalah ummat yang terbaik yang dilahirkan untuk manusia" (al Imran: 110) karena itu semakin islami kepribadian profesi konselor akan semakin besar tingkat keberhasilan layanan konseling.

Berdasarkan latar belakang tersebut, maka tujuan penulisan artikel ini, adalah: Merumuskan karakteristik kepribadian profesi konselor berdasarkan nilai-nilai ajaran agama islam yang bersumber dari al Qur'an, Hadits dan sumber kepustakaan lainnya yang relevan supaya dapat melakukan layanan konseling yang dapat memenuhi tuntutan perubahan dengan segala permasalahannya dan menjawab kebutuhan pengembangan diri di era revolusi 4.0 .

\section{PEMBAHASAN}

Konselor, adalah: orang yang memiliki pengetahuan dan keahlian melakukan pekerjaan layanan konseling. Konselor merupakan profesi yang memiliki landasan keilmuan antar disiplin (Glanding, 2015:8) yaitu: psikologi, sosiologi, antropologi, pendidikan, budaya, ekonomi, filsafat. Masingmasing disiplin ilmu memberi konstribusi sendiri sesuai karakteristik keilmuan dalam pengembangan profesi konselor yang terarah pada pendidikan dan bimbingan, pekerjaan dan karir, perkawinan dan keluarga, dunia usaha dan industri serta bidang kehidupan lain secara utuh dan menyeluruh.

Profesi, merupakan istilah yang selalu dihubungkan dengan pekerjaan tetapi tidak semua pekerjaan dapat disebut sebagai profesi, pekerjaan disebut sebagai profesi apabila memenuhi kreteria berikut: (1) Keintelektualan dan kompetensi profesi, pendidikan yang disyaratkan adalah: S.1 Bimbingan Konseling dan Pendidikan Profesi Konselor (PPK) untuk menguasai teori dan praksis konseling (2) Obyek Praktik Spesifik; pengembangan kehidupan efektif sehari-hari (KES) dan penanganan kehidupan efektif sehari-hari terganggu (KES-T) (3) Motivasi altruistik; layanan profesi untuk membahagiakan konseli (4) Komunikasi dan organisasi profesi; Materi dan proses pendidikan dapat didiskusikan, workshop seminar secara terbuka dan organisasi profesi konselor yang disebut Ikatan Konselor Indonesia (IKI) (Prayitno, 2015: 7)

Layanan konseling merupakan profesi mulia, altruistik (Glanding, 2015: 24) dan profesi yang dinamis yang selalu berubah, kepedulian dan fokus isu layanan tertentu sesuai kebutuhan konseli dan perubahan masyarakat. Pada tahun 1900 di Amerika Serikat awal pertumbuhan konseling fokus pada isu meningkatkan kehidupan orang-orang yang terdesak akibat revolusi industri, selanjutnya pada tahun 1909 Frank Parsons, mengemukakan teori lapangan kerja, maka isu layanan konseling menjadi layanan karir dan saat ini isu yang mendesak dan perlu memperoleh perhatian konseling, adalah: kebutuhan dan perubahan pribadi dan masyarakat akibat revolusi industri 4.0

Di Indonesia, konselor diakui sebagai profesi pada tahun 2003 berdasarkan Undang-Undang No. 20 Tahun 2003 tentang Sistem Pendidikan Nasional, menyebutkan bahwa: "Pendidik merupakan tenaga profesional" dan yang dimaksud pendidik, adalah: tenaga kependidikan yang berkualifikasi sebagai guru, dosen, konselor, pamong belajar, tutor dan sebutan lain yang sesuai dengan kekhususannya serta berpartisipasi dalam menyelenggarakan pendidikan. (Undang-Undang No. 20 Tahun 2003) dengan tugas melaksanakan layanan konseling di sekolah (Peraturan Menteri Pendidikan No. 22 Tahun 2005)

Profesi konselor mengemban visi: terwujudnya kehidupan yang membahagiakan melalui layanan bantuan dalam pemberian dukungan perkembangan diri dan pengentasan masalah agar individu berkembang secara optimal, mandiri dan bahagia. Berdasarkan misi tersebut maka misi layanan konseling difokuskan pada: (1) Misi pendidikan, yaitu mendidik peserta didik dan warga masyarakat melalui pengembangan perilaku efektifnormatif dalam kehidupan sehari-hari dan yang terkait dengan masa depan (2) Misi pengembangan, yaitu: menfasilitasi perkembanan individu sesuai dinamika perkembangan masyarakat (3) Misi pengentasan masalah, yaitu: membantu dan menfasilitasi pengentasan masalah individu mengacu pada kehidupan sehari-hari (Kemendibud, 2004: 1415)

Perkembangan ilmu pengetahuan dan teknologi di era global dan dilanjutkan era revolusi industri 4.0 yang menyebabkan terjadinya perubahan besar-besaran secara cepat dan radikal di masyarakat, kondisi ini mendorong pertubuhan profesi konselor, setting layanan yang semakin luas dengan fokus isu layanan memasuki setting perkawinan dan keluarga, dunia usaha dan idustri, profesi dan karier, kesehatan dan adiksi, kemiskinan dan kebencanaan, anak, remaja dan orang tua sehingga layanan konseling untuk semua (counseling for all) dan layanan konseling sepanjang hayat (lifelong counseling). Untuk menjamin mutu layanan konseling perlu dilakukan standarisasi layanan profesi konselor. (Kemendikbud, 2004: 3) 


\section{Ahmad Hartono \\ Jurnal Bimbingan dan Konseling Ar-Rahman \\ Volume 5, Nomor 1, Tahun 2019 \\ e-ISSN 2477-6300}

Kekuatan eksistensi suatu profesi sebagaimana disampaikan Biggs dan Blocer dalam Umam (2007: tergantung pada pengakuan dan kepercayaan masyarakat (public trust) lebih lanjut Prayitno (2015:8) menjelaskan bahwa profesi konselor yang bermartabat dapat diwujudkan apabila didukung oleh: (1) layanan konseling yang tepat dan bermanfaat (2) pelaksana yang bermandat (3) pengakuan yang sehat dari pihak-pihak yang berkepentingan; pemerintah dan masyarakat.

Profesi konselor dan profesi lain serumpun sebagai profesi bantuan apabila melakukan konseling seuai standar mutu layanan dengan hasil yang tepat dan manfaat yang dapat dirasakan oleh konseli penerima layanan maka akan menjadi profesi yang dipercaya dalam pengembangan diri dan pengentasan masalah. Sehingga profesi konselor adalah profesi kehidupan yang akan terus eksis sepanjang hidup. Dalam perspektf islam pemahaman ini dibangun atas dasar, bahwa: setiap manusia mempunyai potensi yang bisa dikembangkan dan setiap manusia pasti memiliki masalah dalam hidup ini.

Keyakinan bahwa setiap manusia memiliki potensi yang bisa dikembangkan berdasarkan pada firman Allah, berikut: "maka apakah mereka tidak berjalan di muka bumi, lalu mereka mempunyai hati yang dengan itu mereka dapat memahami atau mempunyai telinga yang dengan itu mereka dapat mendengar ? karena sesungguhya bukanlah mata itu yang buta tetapi yang buta ialah hati yang dalam dada (al Hajj/22: 46) dan (2)

Dan kenyataan dalam hidup ini tidak ada orang yang tidak dihadapkan pada cobaan dalam berbagai bentuk sebagai suatu masalah bagi manusia, setiap masalah menuntut untuk dientaskan supaya tidak mengganggu kegiatan efektif sehari-hari sebagaimana dijelaskan al Qur'an berikut: "Dan sungguh akan Kami berikan cobaan kepadamu dengan sedikit ketakutan, kelaparan, kekurangan harta, jiwa dan buah-buahan. Dan berilah kabar gembira kepada orang-orang yang sabar "(al Baqarah/2: 155)

Keberhasilan layanan konseling dan perubahan pada diri konseli dipengaruhi oleh kualitas konselor, ada beberapa karakteristik yang harus dimiliki profesi konselor yang dapat mendukung keberhasilan layanan konseling, menurut Carl Rogers dalam Lesmana (2013: 57) ada 3 karakteristik yang harus dimiliki profesi konselor dalam melaksanakan profesi bantuan (helping profession), yaitu: (1) congruence; kesadaran konselor untuk memahami diri sendiri seperti apa adanya, (2) unconditional positive regard; menerima konseli tanpa syarat, konselor harus respek dan dapat menerima perbedaan nilai dengan konseli dan (3) empathy, yaitu: memahami konseli seperti apa yang dipahami oleh konseli.

Kepribadian konselor adalah sesuatu hal yang sangat penting dalam layanan konseling. Selanjutnya Glanding (2015: 40) mengutip hasil penelitian Mc. Auliffe dan Lovell yang menyebutkan bahwa: pribadi konselor sangat krusial dalam menciptakan perubahan pada diri klien dibandingkan kemampuan mereka menguasai pengetahuan, keahlian atau teknik.

Kepribadian profesi konselor yang islami, yaitu: kepribadian yang dibangun berdasarkan nilainilai ayaran agama islam, yang bersumber dari al Qur'an, hadits dan sumber lain yang relevan. Adapun karakteristik dasar kepribadian profesi konselor islami tersebut, adalah:

Ikhlas, yaitu: kepribadian konselor yang ikhlas sebagaimana difirmankan Allah dalam al Qur'an sebagai berikut: "Padahal mereka tidak disuruh kecuali supaya menyembah Allah dengan memurnikan ketaatan kepada-Nya" (Al Bayyinah/98: 5) layanan konseling yang murni, tulus, guine dari dalam hati semata-mata diniatkan sebagai ibadah kepada Allah, sehingga konselor dapat memahami dirinya seperti apa adanya dan dapat memberikan layanan konseling dengan sepenuh hati dan terjadinya perubahan pada diri konseli secara optimal.

Rahman, konselor merupakan profesi bantuan (helping profession) melalui layanan konseling yang dilakukan konselor dengan penuh kasih-sayang, seperti yang disebutkan dalam al Qur'an berikut: "Dan tiadalah Kami mengutus kamu melainkan untuk menjadi rahmat bagi semesta alam" (Al Anbiya' /21:107) rasa kasih sayang akan menumbuhkan kepekaan perasaan dalam memahami perasaan konseling, dapat menerima konseli dengan lembut, penuh kehangatan dan apa adanya, sehingga konseli merasa aman, diterima, dihargai, akrab yang memudahkan proses dan hasil layanan konseling yang memuaskan konselor dan konseli.

Amanah; artinya terpercaya yang biasanya karakter ini berhubungan dengan karakter ash shidq (kejujuran), tidak ada orang jujur yang tidak terpecaya dan tidak ada orang terpercaya yang tidak jujur. Jujur dalam semua aktivitas hidup; kejujuran niat dalam hati, kejujuran perkataan, kejujuran dalam berazam, kejujuran dalam bekerja sehingga dapat bekerja dengan penuh tanggung jawab dan berkomitmen untuk memberi layanan konseling terbaik sesuai standar mutu profesi, kepribadian ini digambarkan di dalam al Qur'an sebagai berikut: "Ya bapakku ambillah ia sebagai orang yang bekerja (pada kita) karena sesungguhnya orang yang paling baik yang kamu ambil untuk bekerja (pada kita) ialah orang yang kuat lagi dapat dipercaya" (al Qashash/28:26) 


\section{Ahmad Hartono \\ Jurnal Bimbingan dan Konseling Ar-Rahman \\ Volume 5, Nomor 1, Tahun 2019 \\ e-ISSN 2477-6300}

Sabar, merupakan sikap tegar ketika diuji dan dihadapkan kesulitan, tetap teguh dalam kebenaran dan semangat dalam ketaatan dan kebaikan, sabar adalah kunci solusi dari setiap masalah hidup dan inti untuk meraih kebahagiaan, dengan demikian maka sabar adalah kebutuhan bagi konselor dan konseli dalam usaha mewujudkan visi layanan konseling. Hal ini ditegaskan Allah dalam al Qur'an, berikut: "Sifat-sifat yang baik itu tidak dianugerahkan melainkan kepada orang-orang yang sabar dan tidak dianugerahkan melainkan kepada orang yang memiliki keberuntungan yang besar" (Fussilat/41:35) sifat sabar disebutkan pula sebagai berikut: "Dan mintalah pertolongan (kepada Allah) dengan sabar dan shalat" (al Baqarah/2: 45)

Hirsh, perhatian yang besar seorang konselor terhadap konseli, sehingga konseli merasakan adanya perhatian besar tersebut sehingga konseli membuka diri, menerima (acceptance) layanan konseling dapat dilakukan secara konstruktif dan terjadi perubahan efektif pada diri konseli.karakteristik ini digambarkan al Qur'an berikut: "Sesungguhnya telah datang kepadamu seorang rasul dari kaummu sendiri, berat olehmu penderitaanmu, sangat menginginkan (keimanan dan keislaman), amat belas kasihan lagi penyayang terhadap orang-orang yang beriman" (At Taubah/9: 128)

Tsiqoh, kepercayaan konselor terhadap pilihan profesi sebagai profesi bantuan yang mulia dan bermanfaat bagi manusia yang didukung kompetensi untuk melakukan konseling sesuai perkembangan ilmu \& teknologi sehingga tumbuh kepercayaan masyarakat (public trust) terhadap profesi konselor yang memiliki keahlian mengetaskan masalah hidup dan menemukan potensi yang dapat dikembangkan untuk meraih kesuksesan dan kebahagiaan. Sebagaimna difirmakan Allah berikut: "Sesungguhnya Aku bersama kamu, maka teguhlah (pendirian) orang-orang yang beriman (al Anfal/8: 12)

\section{PENUTUP}

Berdasarkan pembahasan kepribadian profesi konselor islami di era industri 4.0 dapat disimpulkan bahwa: dalam nilai-nilai ajaran agama islam terdapat karakteristik kepribadian: ikhlas, rahmah, amanah, sabar, hirsh, tsiqoh yang memiliki kesamaan esensi dan sesuai dengan karakteristik kepribadian yang dituntut untuk menjadi profesi konselor efektif, yaitu: conggruence, unconditional positive regard, empati, tulus, perhatian, jujur, komitmen dan lain sebagainya sehingga semakin islami kepribadian konselor akan semakin efektif melakukan layanan konseling.

Topik layanan konseling yang mendesak untuk diperhatikan di era industri 4.0 adalah: trauma, krisis, kesepian, identitas, kemiskinan, keadilan dan lain sebagainya. Islam sebagai agama yang sempurna dan diridhoi Allah menyimpan khazanah keilmuan yang dapat menjadi solusi mengetaskan masalahmasalah tersebut, Karena itu diwaktu yang akan datang perlu dilakukan kajian dan penelitian terapan di bidang bimbingan konseling berbasis nilai-nilai ajaran islam, misal: sabar dan syukur kunci kebahagian hidup, dzikir sebagai teknik trauma healing, shalat kunci meraih kesuksesan dan keberutungan, dll sehingga islam menjadi solusi dari setiap perubahan di setiap zaman.

\section{REFERENSI}

Direktorat Pembinaan Pendidikan Tenaga Kependidikan dan Ketenagaan Perguruan Tinggi (2004), Dasar Standarisasi Profesi Konseling, Jakarta, Departemen Pendidikan Nasional

Edi Wibowo M.(2017), Tantangan Profesi Bimbingan Konseling Abad 21, Semarang, Universitas PGRI

Gladding Samuel T. (2015), Konseling Profesi yang Menyeluruh, (Terjemahan: P.M. Winarno, Lilian Yuwono) Jakarta, Indeks

Kementerian Agama RI, (1999) Al Qur'an dan terjemahan, Semarang, PenerbitAsy Syifa

Lesmana Jeannette M. (2013) Dasar-dasar Konseling, Jakarta, Penerbit Universitas Indonesia

Prayitno (2013), Konseling Integritas, Padang, Universitas Negeri Padang

Prayitno, (2008), Trilogi Profesi Konselor dan Pengelolaan Berbasis Kinerja, Padang, Universitas Negeri Padang

Prayitno, Amti E. (2015) Dasar-dasar Bimbingan dan Konseling, Jakarta, Rineka Cipta

Prayitno, Marjohan (2015), Pelayanan Profesional Konseling Yang Berhasil, Bogor, Graha Cipta Media

Rakhmawati Dini, Konselor sekolah abad 21: tantangan dan peluang, Jurnal Gusjigang, 3 (1).

Republik Indonesia, Undang-Undang No.20 Tahun 2003 tentang Sistem Pendidikan Nasional, Jakarta, Departemen Pendidikan Nasional

Riswanto Dody, Mappiare Andi AT, Irtadji M, Karakteristik Kepribadian Ideal Konselor (Studi Hermeneutika Gadameria), Jurnal Pendidikan, 1 (11).

Suherman Umam AS (2007), Kompetensi dan aspek etik profesional konselor masa depan, Educationist No.1, Vol.1,ISSN: 1907-8838

Yahya Muhammad (2018), Era Industri 4.0 tantangan dan peluang pengembangan pendidikan kejuruan Indonesia, Makasar, Fakultas Teknik Universitas Negeri Makasar.

Dipublikasikan Oleh :

UPT Publikasi dan Pengelolaan Jurnal

Universitas Islam Kalimantan Muhammad Arsyad Al-Banjari Banjarmasin 